\title{
Plastid DNA variation in Prunus serotina var. serotina (Rosaceae), a North American tree invading Europe
}

\author{
B. Petitpierre - M. Pairon - O. Broennimann • \\ A. L. Jacquemart · A. Guisan · Guillaume Besnard
}

Received: 5 June 2008 / Revised: 6 February 2009 / Accepted: 2 April 2009 / Published online: 6 May 2009

(C) Springer-Verlag 2009

\begin{abstract}
Black cherry (Prunus serotina) is a tree from North America, where it is often used for economical purposes, whereas it is widespread and invasive in Europe. Plastid DNA variation was first investigated in both its native and invasive ranges using microsatellite loci and sequences of three intergenic spacers $(\operatorname{trn} T$ - $\operatorname{trn} L, \operatorname{trn} D$-trnT and $\operatorname{trn} S$-trnG). This analysis was focused on P. serotina var. serotina, with the inclusion of samples of closely related taxa. Length variation at a microsatellite locus (ccmp5) and a few sequence polymorphisms were identified among $P$. serotina samples. Four new primer pairs were then designed to specifically amplify variable regions and a combination of five markers was finally proposed for phylogeographic studies in P. serotina. These loci allow identification of six chlorotypes in P. serotina var. serotina, which may be particularly useful to depict the maternal origins of European invasive populations.
\end{abstract}

Keywords Microsatellite PCR-RFLP · Plastid DNA . Population genetics

Communicated by R. Matyssek.

B. Petitpierre · O. Broennimann · A. Guisan · G. Besnard Department of Ecology and Evolution, Biophore, University of Lausanne, 1015 Lausanne, Switzerland

M. Pairon · A. L. Jacquemart

Research Team Genetics, Reproduction, Populations, Biodiversity Research Center, Université catholique de Louvain, Place Croix du Sud, 2 Bte 14, 1348 Louvain-la-Neuve, Belgium

G. Besnard ( $\square)$

Imperial College London, Silwood Park Campus, Buckhurst Road, Ascot, Berkshire SL5 7PY, United Kingdom e-mail: g.besnard@imperial.ac.uk; gbesnard@unil.ch

\section{Introduction}

Black cherry, Prunus serotina Ehrh. (Rosaceae), is a deciduous tree native to an area ranging from Mexico-Guatemala to south-east Canada (McVaugh 1951; Little 1971). Based on phenotypic characteristics such as the height of the trees and the thickness of the leaves, five varieties are usually recognized: (1) P. serotina var. eximia (Small) Little is confined to the Edwards Plateau in central Texas; $(2,3) P$. serotina var. rufula (Woot. \& Standl.) McVaugh and P. serotina var. virens (Woot. \& Standl.) McVaugh are distributed in Texas, New Mexico and Arizona; (4) P. serotina var. salicifolia (Kunth) Koehne is found from Mexico to Guatemala; and (5) $P$. serotina var. serotina which is the most abundant and common variety and is particularly widespread in the eastern part of the USA and Canada. Black cherry is one of the most valued cabinet and furniture woods in North America (Little 1971) but large, high-quality trees suited for commercial use (belonging to var. serotina) are found in a restricted range on the Allegheny Plateau of Pennsylvania, New York and West Virginia (Hough 1965; Marquis 1975).

Black cherry is now naturalized in several countries in northern South America, such as Ecuador and Peru (EPPO 2007). In Europe, P. serotina var. serotina was first introduced in the early seventeenth century. This tree was recorded in France near Paris around 1630 (Starfinger 2006), in England in 1629 (EPPO 2007) and in Germany in 1685 (Starfinger and Kowarik 2003), where it was particularly appreciated as an ornamental. Since the nineteenth century, the species was massively planted throughout Europe for timber production, but this objective was never achieved because the wood was of poor quality in the introduced range. The species is now widespread and invasive in north-eastern France, Belgium, the Netherlands, Germany, Denmark and Poland and locally abundant in 
Lithuania, Romania, Hungary, Switzerland and Italy (EPPO 2007). Thanks to its tolerance to a very wide range of moisture conditions (Starfinger 2006), black cherry can invade open habitats such as dry grasslands and heathlands. $P$. serotina also benefits from anthropogenic influences such as soil disturbance and/or eutrophication (Godefroid et al. 2005). P. serotina disperses by seed (mainly through birds and frugivore mammals; Starfinger 2006) but also exhibits very efficient vegetative reproduction by suckering and sprouting. If sufficiently exposed to light, trees produce abundant quantities of seeds (up to 10,000 per tree in invasive populations; Pairon et al. 2006) after the age of approximately seven.

The use of genetic markers should be helpful to discern high-quality tree lineages in the native range and to depict the pattern of introduction of $P$. serotina in Europe (e.g. Freeman et al. 2007). The plastid genome (cpDNA) is usually inherited from the female parent (as already reported in other Prunus species; Brettin et al. 2000; Mohanty et al. 2003) and only dispersed by seeds. Thus, the use of cpDNA markers is often more efficient to detect colonization routes than nuclear markers (e.g. Petit et al. 2005) and is informative to depict the pattern of invasion. The combined use of plastid and nuclear markers is also very informative for a comparative study of gene dispersal by seeds versus pollen (seed- or pollen-mediated gene flow). However, plastid DNA variation can be particularly low in forest trees (e.g. Magri et al. 2007; Besnard 2008; Vendramin et al. 2008).
Moreover, one can expect that European P. serotina populations could be genetically depauperate due to bottleneck effects, putatively leading to difficulties in the detection of useful polymorphisms for population genetic studies in the invasive area. Nevertheless, the successful use of highly variable cpDNA microsatellites has been reported for numerous trees (e.g. Harbourne et al. 2005; Magri et al. 2007) and such a methodology should be tested on P. serotina.

In the present paper, we investigate cpDNA polymorphism in P. serotina var. serotina using seven universal cpDNA microsatellite loci (Weising and Gardner 1999) and sequences of three intergenic spacers. Based on sequence polymorphism, new primers for the characterization of polymorphic loci are developed to easily characterize large samples of trees. Lastly, a combination of loci for cpDNA genetic studies of $P$. serotina var. serotina is proposed to allow efficient characterization of cpDNA variation in black cherry populations.

\section{Material and methods}

\section{Plant sampling and DNA extraction}

Eleven populations of $P$. serotina var. serotina were sampled throughout its distribution in both the native and invasive ranges (Table 1). Five individuals per population were collected at least $15 \mathrm{~m}$ from each other. In addition, two
Table 1 Description of the Prunus serotina and $P$. virginiana populations analysed in the present study, including population code (Pop. code), geographic location, GPS coordinates, number of individuals characterized $(N)$ and detected haplotypes

a see Tables 2 and 3 for haplotype definition

\begin{tabular}{|c|c|c|c|c|c|c|}
\hline \multirow[t]{2}{*}{ Taxon } & \multirow[t]{2}{*}{ Location } & \multirow[t]{2}{*}{ Pop. code } & \multicolumn{2}{|c|}{ GPS coordinates } & \multirow[t]{2}{*}{$N$} & \multirow[t]{2}{*}{ Haplotypes $^{\mathrm{a}}$} \\
\hline & & & Latitude & Longitude & & \\
\hline \multicolumn{7}{|c|}{ Prunus serotina } \\
\hline \multirow[t]{13}{*}{ var. serotina } & Native range (USA) & & & & & \\
\hline & Charleston, South Carolina & $\mathrm{SC} 1$ & $32.45^{\circ} \mathrm{N}$ & $79.54^{\circ} \mathrm{W}$ & 5 & ss 4, ss 5 \\
\hline & Spruce Knob, Virginia & WV1 & $38.71^{\circ} \mathrm{N}$ & $79.54^{\circ} \mathrm{W}$ & 5 & ss4 \\
\hline & Ashville, Ohio & $\mathrm{OH} 3$ & $39.67^{\circ} \mathrm{N}$ & $82.93^{\circ} \mathrm{W}$ & 5 & ss1 \\
\hline & Omaha, Nebraska & NE2 & $41.25^{\circ} \mathrm{N}$ & $96.00^{\circ} \mathrm{W}$ & 5 & ss 1, ss2 \\
\hline & Ames, Iowa & IO1 & $41.35^{\circ} \mathrm{N}$ & $92.30^{\circ} \mathrm{W}$ & 5 & ss $1, \mathrm{ss} 2$ \\
\hline & Buckaloons, Pennsylvania & PE2 & $41.80^{\circ} \mathrm{N}$ & $79.25^{\circ} \mathrm{W}$ & 5 & ss $1, \mathrm{ss} 3, \mathrm{ss} 4$ \\
\hline & Denton Hill, Pennsylvania & PE7 & $41.77^{\circ} \mathrm{N}$ & $77.82^{\circ} \mathrm{W}$ & 5 & ss1, ss4 \\
\hline & Invasive range (Europe) & & & & & \\
\hline & Ticino, Italy & IT1 & $45.52^{\circ} \mathrm{N}$ & $08.72^{\circ} \mathrm{E}$ & 5 & ss6 \\
\hline & Fontainebleau, France & FR1 & $48.38^{\circ} \mathrm{N}$ & $02.75^{\circ} \mathrm{E}$ & 5 & ss 3 \\
\hline & Shakelford, UK & UK1 & $51.18^{\circ} \mathrm{N}$ & $00.65^{\circ} \mathrm{W}$ & 5 & ss 4 \\
\hline & Aarhus, Denmark & DA3 & $56.18^{\circ} \mathrm{N}$ & $09.65^{\circ} \mathrm{E}$ & 5 & ss1, ss4 \\
\hline \multirow[t]{2}{*}{ var. rufula } & Native range (USA) & & & & & \\
\hline & Tanque Verde, Arizona & AZ1 & $32.37^{\circ} \mathrm{N}$ & $110.69^{\circ} \mathrm{W}$ & 2 & $\operatorname{sr} 1$ \\
\hline \multirow[t]{3}{*}{ P. virginiana } & Native range (USA) & & & & & \\
\hline & Chloride, New Mexico & NM1 & $33.35^{\circ} \mathrm{N}$ & $107.89^{\circ} \mathrm{W}$ & 1 & v1 \\
\hline & Cloudcroft, New Mexico & NM2 & $32.96^{\circ} \mathrm{N}$ & $105.75^{\circ} \mathrm{W}$ & 1 & $\mathrm{v} 1$ \\
\hline
\end{tabular}


individuals of both $P$. serotina var. rufula and $P$. virginiana (a species closely related to $P$. serotina; Shaw and Small 2004) were also collected in Arizona and New Mexico, respectively (Table 1). A total of 59 individuals were characterized. Approximately $20 \mathrm{mg}$ of dry leaf material was ground in a 2-ml Eppendorf tube using a Tissuelyzer (QIAGEN) and three tungsten balls in each tube. Genomic DNA was extracted using a DNA-mini-extraction Kit (QIAGEN) according to the manufacturer's protocol.

\section{Plastid DNA characterization}

In order to characterize maternally inherited polymorphisms, seven cpDNA microsatellite loci (ccmp2, ccmp3, ccmp4, ccmp5, ccmp6, ccmp7 and ccmp10; Weising and Gardner 1999) were first tested on all samples. Each PCR reaction $(25 \mu \mathrm{l})$ contained $10 \mathrm{ng}$ DNA template, $1 \times$ reaction buffer, $0.2 \mathrm{mM}$ dNTPs, $0.2 \mu \mathrm{mol}$ of each primer (one labelled with a fluorochrome), and $0.75 \mathrm{U} \mathrm{Taq}$ DNA polymerase (GoTaq, Promega, Madison, WI, USA). Reaction mixtures were incubated in a thermocycler (T1; Biometra, Göttingen, Germany) for $3 \mathrm{~min}$ at $94^{\circ} \mathrm{C}$, followed by 36 cycles of $45 \mathrm{~s}$ at $94^{\circ} \mathrm{C}, 45 \mathrm{~s}$ at $53^{\circ} \mathrm{C}$, and $60 \mathrm{~s}$ at $72^{\circ} \mathrm{C}$. The last cycle was followed by a 10 -min extension at $72^{\circ} \mathrm{C}$. Electrophoresis procedures were used as described by Basic and Besnard (2006).

Three non-coding plastid regions (trnT-trnL, trnD-trnT and $\operatorname{trnS}$-trnG) were sequenced on one $P$. virginiana tree (NM2) and eight $P$. serotina individuals originating from distant populations in the native (AZ1-1, NE2-1, PE7-2, IO1-7, SC1-2) and invasive ranges (UK1-1, IT1-8, FR1-4). For the PCR reactions, we used either universal primers for trnT-trnL (Taberlet et al. 1991) and trnD-trnT (Demesure et al. 1995) or new specific primers for $\operatorname{trnS}$ - trnG $(\operatorname{trnS}$ trnG-For: 5'GTGAAACTTTGGTTTCATC3' and $t r n s$ trnG-Rev: 5'GAAAAAAGAGAAGACTATGTTAC3'). Each PCR reaction $(50 \mu \mathrm{l})$ contained $10 \mathrm{ng}$ DNA template, $1 \times$ reaction buffer, $0.2 \mathrm{mM}$ dNTPs, $0.2 \mu \mathrm{mol}$ of each primer, and $0.75 \mathrm{U}$ Taq DNA polymerase (GoTaq). Reaction mixtures were incubated in a thermocycler (T1; Biometra) for $3 \mathrm{~min}$ at $94^{\circ} \mathrm{C}$, followed by 36 cycles of $45 \mathrm{~s}$ at $94^{\circ} \mathrm{C}, 45 \mathrm{~s}$ at $53^{\circ} \mathrm{C}$, and $120 \mathrm{~s}$ at $72^{\circ} \mathrm{C}$. The last cycle was followed by a 10 -min extension at $72^{\circ} \mathrm{C}$. PCR products were then purified using a QIAquick Purification Kit (QIAGEN) following the manufacturers' protocol. Direct sequencing was performed using Big Dye 3.1 Terminator sequencing cycle (Applied Biosystems) according to manufacturer's instructions and an ABI PRISM 3100 genetic analyser (Applied Biosystems).

Based on cpDNA sequences, four markers were developed to characterize our plant samples (Fig. 1). Primers (Table 2) were designed in regions flanking polymorphisms (i.e. nucleotide substitutions or length polymorphisms).
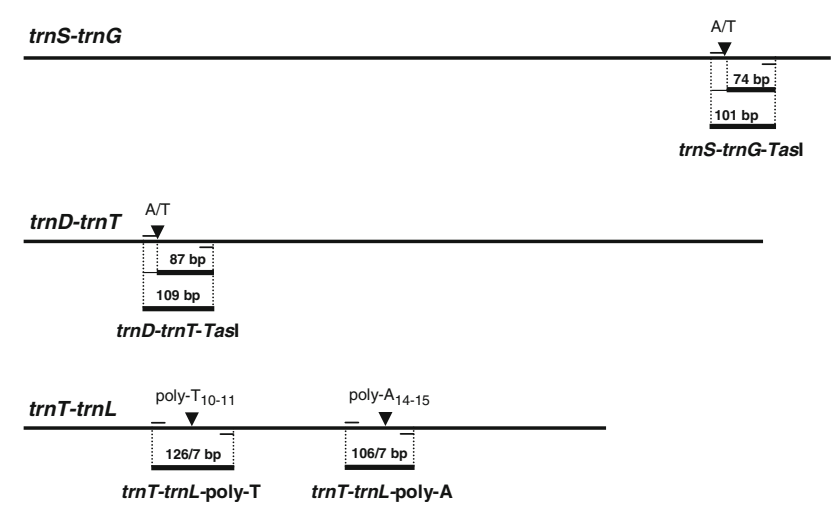

$\longmapsto 100$ bp

Fig. 1 Position of the two A/T nucleotide substitutions (A/T) and two length polymorphisms (poly-T or poly-A) detected in the plastid spacers $\operatorname{trnS}$-trn $G(1,225 \mathrm{bp}), \operatorname{trn} D$-trnT $(1,122 \mathrm{bp})$ and $\operatorname{trn} T$-trnL ( $884 \mathrm{bp})$ of Prunus serotina. The four developed markers, with the position of each primer (-), are also indicated. For PCR-RFLP loci (trnS-trnGTasI and $\operatorname{trn} D$-trnT-TasI), the size of length variants is given after restriction by TasI

Each PCR reaction $(25 \mu \mathrm{l})$ contained $10 \mathrm{ng}$ DNA template, $1 \times$ reaction buffer, $0.2 \mathrm{mM}$ dNTPs, $0.2 \mu \mathrm{mol}$ of each primer (one labelled with a fluorochrome; Table 2), and 0.75 U Taq DNA polymerase (GoTaq). Reaction mixtures were incubated in a thermocycler (T1; Biometra) for $3 \mathrm{~min}$ at $94^{\circ} \mathrm{C}$, followed by 36 cycles of $30 \mathrm{~s}$ at $94^{\circ} \mathrm{C}, 30 \mathrm{~s}$ at the defined annealing temperature (Table 2) and $30 \mathrm{~s}$ at $72^{\circ} \mathrm{C}$. The last cycle was followed by a 10 -min extension at $72^{\circ} \mathrm{C}$. Furthermore, in trnD-trnT-TasI and trnS-trnG-TasI, two T/A nucleotide substitutions (leading to TasI restrictionsite polymorphisms) were investigated using the restriction fragment length polymorphism (RFLP) methodology. Digestion of the PCR fragments was performed using the restriction enzyme TasI (Fermentas, St Leon-Rot, Germany) according to the manufacturer's recommendations. Electrophoresis procedures were used as described by Basic and Besnard (2006).

Data analysis

The total gene diversity $\left(H_{\mathrm{T}}\right)$ was estimated using $F_{\text {STAT }}$ (Goudet 2005) for both native and invasive populations of $P$. serotina var. serotina. This parameter was estimated for each locus and on the multi-locus profiles (considered as alleles from one locus). The mean within-population gene diversity $\left(H_{\mathrm{S}}\right)$ was also estimated for native and invasive populations on the multi-locus profiles. A test for a significant difference of within-population gene diversity between native and invasive populations was ascertained using comparisons among groups of samples as implemented in $F_{\text {STAT }}$ with 10,000 permutations of individuals among groups tested. In addition, a reduced median network for $P$. serotina haplotypes was built based on the combined PCR-RFLP 
Table 2 Characteristics of new primers used to characterize cpDNA polymorphisms in Prunus serotina, including annealing temperature $\left(T_{\mathrm{a}}\right)$ in ${ }^{\circ} \mathrm{C}$, the number of alleles $(N)$ and the size of alleles in bp

\begin{tabular}{|c|c|c|c|c|c|}
\hline Locus & GenBank & Primers & $T_{\mathrm{a}}$ & $N$ & Allele sizes $^{a}$ \\
\hline trnS-trnG-TasI & $\begin{array}{l}\text { AM950170 } \\
\text { to AM950177 }\end{array}$ & $\begin{array}{l}\text { For:5'CTATAATCATAGAAATCTAAATAAACA3' } \\
\text { Rev: FAM-5'TCGTAAATAAACTGATTTATTTGATT3' }\end{array}$ & 47 & 2 & $\begin{array}{l}\text { A) } 101 \rightarrow 74^{\mathrm{b}}+27 \\
\text { B) } 101 \rightarrow 101^{\mathrm{b}}\end{array}$ \\
\hline trnD-trnT-TasI & $\begin{array}{l}\text { AM950153 } \\
\text { to AM950160 }\end{array}$ & $\begin{array}{l}\text { For: 5'GGATAATCACTCTTTCAATGT3' } \\
\text { Rev: HEX-5'AATTCTGATCTTGCTAATGATC3' }\end{array}$ & 50 & 2 & $\begin{array}{l}\text { A) } 109 \rightarrow 87^{b}+22 \\
\text { B) } 109 \rightarrow 109^{b}\end{array}$ \\
\hline $\operatorname{trn} T$-trnL-poly-T & $\begin{array}{l}\text { AM950162 } \\
\text { to AM950169 }\end{array}$ & $\begin{array}{l}\text { For: FAM-5'ATTAGCTTAATTAGATAGTAAG3' } \\
\text { Rev: 5'CCGTTAATTTATAATTAGAAGA3' }\end{array}$ & 47 & 2 & 126,127 \\
\hline $\operatorname{trn} T$-trnL-poly-A & $\begin{array}{l}\text { AM950162 } \\
\text { to AM950169 }\end{array}$ & $\begin{array}{l}\text { For: 5'TAATTCAGATCATAATGAAACA3' } \\
\text { Rev: FAM-5'GTGCAATTTTGAATACTTGAA3' }\end{array}$ & 47 & 2 & 106,107 \\
\hline
\end{tabular}

${ }^{a}$ For $\operatorname{trnS}$-trnG-TasI and trnD-trnT-TasI, the size of fragments before and after $(\rightarrow)$ restriction is given

${ }^{b}$ DNA fragment labelled with the fluorochrome (FAM or HEX)

Table 3 Multi-locus profiles of the eight cpDNA haplotypes detected in Prunus serotina (ss1 to ss6 in var. serotina, and sr1 in var. rufula) and $P$. virginiana (v1)

The length (in bp) of each sized DNA fragment is given. Gene diversities in the native $\left[H_{\mathrm{T}(\mathrm{N})}\right]$ and invasive $\left[H_{\mathrm{T}(\mathrm{I})}\right]$ ranges are given for the $P$. serotina var. serotina populations

\begin{tabular}{|c|c|c|c|c|c|c|c|c|c|c|}
\hline \multirow[t]{2}{*}{ Locus } & \multicolumn{8}{|c|}{ Multi-locus profile (haplotype) } & \multirow[t]{2}{*}{$H_{\mathrm{T}(\mathrm{N})}$} & \multirow[t]{2}{*}{$H_{\mathrm{T}(\mathrm{I})}$} \\
\hline & ss 1 & ss2 & ss3 & ss4 & ss 5 & ss6 & sr1 & v1 & & \\
\hline ccmp2 & 204 & 204 & 204 & 204 & 204 & 204 & 204 & 202 & 0 & 0 \\
\hline ccmp3 & 105 & 105 & 105 & 105 & 105 & 105 & 105 & 125 & 0 & 0 \\
\hline ccmp4 & 118 & 118 & 118 & 118 & 118 & 118 & 118 & 118 & 0 & 0 \\
\hline ccmp5 & 126 & 126 & 126 & 126 & 125 & 126 & 129 & 127 & 0.057 & 0 \\
\hline ccmp6 & 111 & 111 & 111 & 111 & 111 & 111 & 111 & 110 & 0 & 0 \\
\hline ccmp7 & 133 & 133 & 133 & 133 & 133 & 133 & 133 & 133 & 0 & 0 \\
\hline ccmp10 & 113 & 113 & 113 & 113 & 113 & 113 & 113 & 113 & 0 & 0 \\
\hline trnS-trnG-TasI & 101 & 101 & 74 & 101 & 101 & 101 & 101 & 68 & 0.057 & 0.375 \\
\hline trnD-trnT-TasI & 87 & 87 & 87 & 109 & 109 & 109 & 87 & 86 & 0.514 & 0.488 \\
\hline trnT-trnL-poly-T & 126 & 126 & 126 & 126 & 126 & 127 & 126 & 131 & 0 & 0.375 \\
\hline trnT-trnL-poly-A & 106 & 107 & 106 & 106 & 106 & 106 & 106 & 107 & 0.248 & 0 \\
\hline Total & - & - & - & - & - & - & - & - & 0.661 & 0.738 \\
\hline
\end{tabular}

and microsatellite data. Nucleotide polymorphisms were coded as present/absent and length variations at microsatellite loci were coded as multistate characters. This maximum-parsimony analysis was performed using the NETWORK software (http://www.fluxus-engineering. com/sharenet.htm; Bandelt et al. 1999).

\section{Results and discussion}

The characterization of all samples with seven ccmp loci (Weising and Gardner 1999) allowed clear distinction between $P$. virginiana and $P$. serotina (using length variation at ccmp2, ccmp3, ccmp5 and ccmp6; Table 3). This result supports that these two species are phylogenetically differentiated based on maternal markers. In addition, our samples of $P$. serotina var. serotina and var. rufula can be distinguished based on ccmp5 (Table 3 ). In P. serotina var. serotina, only one locus (ccmp5) was variable with one tree from SC1 (SC1-2) displaying a rare variant (i.e. $125 \mathrm{bp})$.

The lack of genetic polymorphism in P. serotina var. serotina revealed by the ccmp loci led us to investigate DNA sequence polymorphism in the intergenic spacers trnT-trnL (884 bp), trnD-trnT (1,122 bp) and trnS-trnG (1,225 bp). In $P$. serotina, only four variable sites were found (Fig. 1), but no new specific polymorphism was detected in the sample of var. rufula compared to samples of var. serotina. On the $\operatorname{trnD}$-trnT and $\operatorname{trnS}$-trnG spacers, one T/A substitution (creating TasI restriction-site polymorphism) was found at positions 200 and 1061, respectively. On trnT-trnL, two length polymorphisms of $1 \mathrm{bp}$ were found at positions 257 and 551, respectively, in a poly- $\mathrm{T}\left(\mathrm{T}_{10-11}\right)$ and a poly-A $\left(\mathrm{A}_{14-15}\right)$.

Four cpDNA primer pairs were developed (Table 2; Fig. 1) to amplify and characterize these polymorphisms on all samples. Length variation revealed on both trnT-trnL markers (poly-T and poly-A) was fully congruent with our 


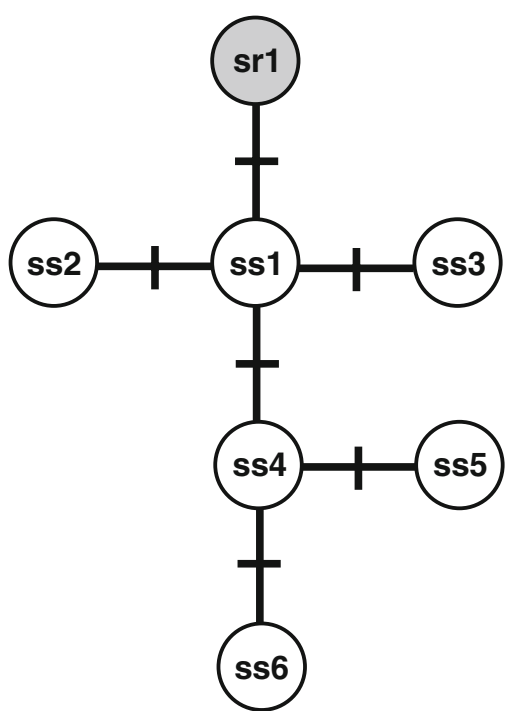

Fig. 2 Reduced median network representing phylogenetic relationships of plastid DNA haplotypes of Prunus serotina var. serotina. Each haplotype is coded as reported in Table 3. Haplotype sr1 (P. serotina var. rufula) is used as outgroup. This analysis is performed on five polymorphic loci

sequence data. Our markers revealed various levels of gene diversity $\left(H_{\mathrm{T}}\right)$ and the most discriminating locus in both ranges was $\operatorname{trn} D$-trnT-TasI $\left(H_{\mathrm{T}} \approx 0.5\right.$; Table 3$)$. Combining these loci with ccmp5, six haplotypes (named ss1, ss2, ss3, ss4, ss5 and ss6) were found in P. serotina var. serotina (Table 3). The reconstructed network (Fig. 2) showed that haplotypes are all interconnected with ss1 and ss 4 at central positions. The outgroup haplotype ( $\mathrm{sr} 1)$ is branched on ss1 suggesting that the latter probably represents the ancestral profile. Three haplotypes (ss1, ss3 and ss4) were shared by both native and invasive populations, two haplotypes (ss2 and ss5) were just detected in the native area and one haplotype (ss6) was only found in the invasive range. Surprisingly, in our sample the global gene diversity was similar between the native $\left(H_{\mathrm{T}}=0.661\right)$ and invasive ranges $\left(H_{\mathrm{T}}=0.738\right)$. The mean within-population gene diversity was also not significantly different between native $\left(H_{\mathrm{S}}=0.329\right)$ and invasive $\left(H_{\mathrm{S}}=0.150\right)$ populations $(P=0.241)$. These observations suggest that there was not important reduction of gene diversity during the invasion. Interestingly, intrapopulation variation was also detected in several populations and even in the invasive range (PE2, PE7, IO1, NE2, SC1 and DA3; Table 1).

This study has shown that, even in the presence of low sequence polymorphism, substantial cpDNA diversity can be detected throughout the $P$. serotina distribution. Plastid DNA markers may be very useful for population genetic studies in P. serotina, and particularly here for var. serotina for which we recommend the combined use of three microsatellite loci (i.e. ccmp5, $\operatorname{trnT}$-trnL-poly-T and $\operatorname{trnT}$-trnL-poly-A) and two PCR-RFLPs (i.e. $t r n S$ trnG-TasI, trnD-trnT-TasI). Moreover, their combined use with nuclear SSR markers (Pairon et al. 2008) will also help to depict the origins and dispersal of invasive populations in Europe. The presence of distinct cpDNA haplotypes in Europe supports the hypothesis of multiple introductions in the invasive range. The molecular characterization of a more exhaustive sample in both the native and invasive ranges is now necessary to better document these introductions and then identify the pattern of colonization of this invasive species (M. Pairon in prep.; B. Petitpierre et al., in prep.). Detection of the different invasive forms could also open new perspectives to understand invasion of the tree, particularly by integrating such information in niche-based modelling (Mau-Crimmins et al. 2006; Broennimann et al. 2007).

Acknowledgments This research was funded by the National Centre of Competence in Research (NCCR) Plant Survival, research program of the Swiss National Science Foundation. M. Pairon and A.L. Jacquemart were supported by the Fonds Spéciaux de Recherche (FSR) of the Université catholique de Louvain (UCL) and the Belgian Scientific Policy (BelSPo-InPlanBel). M. Pairon is research fellow of the Belgian National Fund of Scientific Research and A.L. Jacquemart is research associate in the same institution. Collection of the samples was partly funded by grants to K.O. Reinhart from Highlands Biological Station and from the A.W. Mellon Foundation helping form a partnership between the National Park Service, the Ecological Society of America and the National Park Foundation. We are grateful for the kind collaboration of many foresters and scientists who helped collecting leaves of $P$. serotina and $P$. virginiana: P.J. Alexander and D. Bailey (New Mexico State University), M. Campbell (Pennsylvania State University), F. Caronni and L. Hildebrand (Parco Lombardo della Valle del Ticino), G. Decocq (University of Picardie), R.B. Kaul and D.M. Sutherland (University of Nebraska), R.A. Klips (Ohio State University), P. Jenkins and J. Tedford (University of Arizona), D.A. Lewis (Iowa State University), N.P. Revsbech (University of Aarhus). We also thank D. Potter and an anonymous reviewer for their constructive comments.

\section{References}

Bandelt HJ, Forster P, Röhl A (1999) Median-joining networks for inferring intraspecific phylogenies. Mol Biol Evol 16:37-48

Basic N, Besnard G (2006) Gene polymorphisms for elucidating the genetic structure of the heavy-metal hyperaccumulating trait in Thlaspi caerulescens and their cross-genera amplification in Brassicaceae. J Plant Res 119:479-487. doi:10.1007/s10265-0060011-x

Besnard G (2008) Chloroplast DNA variations in Mediterranean olive. J Hortic Sci Biotechnol 83:51-54

Brettin TS, Karle R, Crowe EL, Iezonni AF (2000) Chloroplast inheritance and DNA variation in sweet, sour and ground cherry. J Hered 91:75-79. doi:10.1093/jhered/91.1.75

Broennimann O, Treier UA, Müller-Schärer H, Thuiller W, Peterson AT, Guisan A (2007) Evidence of climatic niche shift during biological invasion. Ecol Lett 10:701-709. doi:10.1111/j.14610248.2007.01060.x

Demesure B, Sodzi N, Petit RJ (1995) A set of universal primers for amplification of polymorphic non-coding regions of mitochondrial 
and chloroplast DNA in plants. Mol Ecol 4:129-131. doi:10.1111/j.1365-294X.1995.tb00201.x

EPPO (2007) List of invasive alien plants (accessed on 12/17/2007 from http://www.eppo.org/QUARANTINE/ias_plants.htm)

Freeman JS, Marques CMP, Carocha V, Borralho N, Potts BM, Vaillancourt RE (2007) Origins and diversity of the Portuguese Landrace of Eucalyptus globulus. Ann For Sci 64:639-647. doi:10.1051/forest:2007042

Godefroid S, Phartyal SS, Weyembergh G, Koedam N (2005) Ecological factors controlling the abundance of non-native invasive black cherry (Prunus serotina) in deciduous forest understory in Belgium. For Ecol Manag 210:91-105. doi:10.1016/j.foreco. 2005.02.024

Goudet J (2005) FSTAT (version 2.9.4): a program to estimate and test population genetics parameters. http://www2.unil.ch/popgen/ softwares/fstat.htm

Harbourne ME, Douglas GC, Waldren S, Hodkinson TR (2005) Characterization and primer development for amplification of chloroplast microsatellite regions of Fraxinus excelsior. J Plant Res 118:339-345. doi:10.1007/s10265-005-0223-5

Hough AF (1965) Black Cherry (Prunus serotina Hehrh.). Silvics of forest trees of the United States. In: Fowells HA (ed) Agricultures handbook 271. US Department of Agriculture, Washington, DC, pp 539-545

Little EL Jr (1971) Atlas of United States trees, vol 1, conifers and important hardwoods. US Department of Agriculture Miscellaneous Publication No. 1146, Washington

Magri D, Fineschi S, Bellarosa R, Buonamici A, Sebastiani F, Schirone B, Simeone MC, Vendramin GG (2007) The distribution of Quercus suber chloroplast haplotypes matches the palaeogeographical history of the western Mediterranean. Mol Ecol 16:5259-5266

Marquis DA (1975) The Allegheny hardwood forests of Pennsylvania. USDA Forest Service, general technical report NE-15. Northeastern Forest Experiment Station, Upper Darby, 32p

Mau-Crimmins TM, Schussman HR, Geiger EL (2006) Can the invaded range of a species be predicted sufficiently using only nativerange data? Lehmann lovegrass (Eragrostis lehmanniana) in the southwestern United States. Ecol Model 93:736-746. doi:10.1016/ j.ecolmodel.2005.09.002
McVaugh R (1951) A revision of the north American black cherries (Prunus serotina Ehrh., and relatives). Brittonia 7:279-315. doi: $10.2307 / 2804698$

Mohanty A, Martín JP, González LM, Aguinagalde I (2003) Association between chloroplast DNA and mitochondrial DNA haplotypes in Prunus spinosa L. (Rosaceae) populations across Europe. Ann Bot (Lond) 92:749-755. doi:10.1093/aob/mcg 198

Pairon M, Chabrerie O, Mainer Casado C, Jacquemart AL (2006) Sexual regeneration traits linked to black cherry (Prunus serotina Ehrh.) invasiveness. Acta Oecol 30:238-247. doi:10.1016/ j.actao.2006.05.002

Pairon M, Jacquemart AL, Potter D (2008) Detection and characterization of genome-specific microsatellite markers in the allotetraploid Prunus serotina. J Am Soc Hortic Sci 133:390-395

Petit RJ, Duminil J, Fineschi S, Hampe A, Salivini D, Vendramin GG (2005) Comparative organization of chloroplast, mitochondrial and nuclear diversity in plant populations. Mol Ecol 14:689-701. doi:10.1111/j.1365-294X.2004.02410.x

Shaw J, Small RL (2004) Addressing the 'hardest puzzle in American pomology:' phylogeny of Prunus sect. Prunocerasus (Rosaceae) based on seven noncoding chloroplast DNA regions. Am J Bot 91:985-996. doi:10.3732/ajb.91.6.985

Starfinger U (2006) NOBANIS-invasive alien species fact sheetPrunus serotina. Online database of the North European and Baltic network on invasive alien species (accessed on 12/17/2007 from www.nobanis.org)

Starfinger U, Kowarik I (2003) Prunus serotina Ehrh. (Rosaceae), Späte Traubenkirsch. Neoflora fact sheet (accessed on 01/22/2008 from http://www.floraweb.de/neoflora/handbuch/prunusserotina.pdf)

Taberlet P, Gielly L, Pautou G, Bouvet J (1991) Universal primers for amplification of three non-coding regions of chloroplast DNA. Plant Mol Biol 17:1105-1109. doi:10.1007/BF00037152

Vendramin GG, Fady B, González-Martínez SC, Sheng Hu F, Scotti I, Sebastiani F, Soto A, Petit RJ (2008) Genetically depauperate but widespread: the case of an emblematic Mediterranean pine. Evolution Int J Org Evol 62:680-688. doi:10.1111/j.1558-5646.2007.00294.x

Weising K, Gardner RC (1999) A set of conserved PCR primers for the analysis of simple sequence repeat polymorphisms in chloroplast genomes of dicotyledonous angiosperms. Genome 42:9-19. doi:10.1139/gen-42-1-9 